\title{
STUF EX DALAM NAPKING FOLDING BAGI PESERTA DIDIK BERKEBUTUHAN KHUSUS
}

\author{
Indria Ariyanti \\ e-mail : indriaariyanti31@gmail.com
}

\begin{abstract}
Abstrak: Saat ini sudah banyak sekolah umum yang menyelenggarakan pendidikan untuk peserta didik berkebutuhan khusus bersama dengan kelas reguler. SMK Negeri 3 Probolinggo sudah melaksanakan pendidikan integrasi dengan menerima peserta didik berkebutuhan khusus pada 5 program keahlian. Program keahlian Tata Boga pada kelas XI ada 3 peserta didik berkebutuhan khusus menyandang ketunaan 2 orang tuna grahita dan 1 orang tuna rungu dan wicar. Adanya peserta didik berkebutuhan khusus di kelas reguler, guru mengalami kesulitan berkomunikasi dalam proses pembelajaran dan kesulitan untuk menentukan metode pembelajaran untuk peserta didik berkebutuhan khusus. Dalam proses pembelajaran Tata Hidang kompetensi dasar membuat lipatan serbet atau napkin folding diharapkan anak terampil dalam membuat berbagai macam bentuk napkin folding. Untuk peserta didik berkebutuhan khusus merasa kesulitan dalam melakukan praktik napkin folding. Strategi yang dipilih dalam proses pembelajaran praktik napkin folding adalah dengan menerapkan model STUF EX berbantukan hand out. Langkah-langkah pemecahan masalah menggunakan model Student Facilitator And Explaining secara garis besar meliputi perencanaan, pelaksanaan dan evaluasi. Setelah menerapkan model pembelajaran STUF EX dengan penekanan pada keaktifan anak, banyak perubahan yang terjadi pada peserta didik berkebutuhan khusus. Perubahan itu penulis ketahui dari observasi pada aktifitas peserta didik berkebutuhan khusus pada saat mengikuti pembelajaran dan hasil perkembangan belajar peserta didik berkebutuhan khusus. Perubahan itu antara lain bagi Peserta didik berkebutuhan khusus dapat menerima penjelasan dari temannya sebagai fasilitator. Sehingga peserta didik berkebutuhan khusus dengan senang hati mau mempraktikkan napkin folding sesuai langkah-langkah yang diajarkan. Model ini efektif meningkatkan komunikasi antara guru dan anak peserta didik serta komunikasi peserta didik dengan peserta didik. Hasil yang didapatkan peserta didik berkebutuhan khusus menjadi tertarik untuk belajar bersama teman-temannya. Peranan guru dan teman di kelas intregasi sangat membantu proses belajar peserta didik berkebutuhan khusus sehingga mereka tidak merasa terabaikan. Pergaulan sosial dengan teman-teman yang mau menerima keadaan mereka menambah semangat peserta didik berkebutuhan khusus untuk belajar. Secara keseluruhan dapat disimpulkan Model STUF EX berbantukan hand out dapat meningkatkan hasil belajar peserta didik berkebutuhan khusus atas nama Farah dan Fian. Peningkatan hasil belajar peserta didik berkebutuhan khusus dibuktikan dengan hasil praktik sebelum menggunakan model STUF EX, mereka kesulitan dalam praktik melipat serbet (napkin folding). Setelah menggunakan model STUF EX ada peningkatan hasil praktik melipat serbet (napkin folding) cukup sesuai dengan standar penilaian melipat serbet (napkin folding).
\end{abstract}

Kata Kunci : model pembelajaran, stuf ex, napkin folding, Student facilitator and Explaining 


\section{Pendahuluan}

Setiap warga negara Indonesia mempunyai hak untuk memperoleh pendidikan tanpa adanya perbedaan. Seperti tertuang dalam Undang-undang Dasar 1945 pasal 31 ayat 1 dan Undang-undang nomor 20 tahun 2003 tentang Pendidikan Nasional yang menyatakan bahwa setiap warga negara mempunyai kesempatan yang sama dalam memperoleh pendidikan. Hal ini menunjukkan bahwa dalam memperoleh pendidikan tidak membedakan peserta didik reguler maupun peserta didik berkebutuhan khusus.

Peserta didik berkebutuhan khusus seperti peserta didik reguler lainnya mempunyai hak yang sama untuk mendapatkan layanan pendidikan yang layak. Pada saat ini sudah banyak sekolah umum yang menyelenggarakan pendidikan untuk peserta didik berkebutuhan khusus bersama dengan kelas reguler. 'Pendidikan umum yang memadukan anak-peserta didik berkebutuhan khusus belajar di sekolah umum dengan anak-anak pada umumnya disebut pendidikan Integrasi. Dalam pendidikan Integrasi anak-anak yang memiliki karakteristik khusus dianggap sama dengan anak-peserta didik reguler'. Reid dan Knigt( Dalam Modul Pendidikan Inklusif Berbasis Sekolah, 2013:30)

SMK Negeri 3 Probolinggo sudah melaksanakan pendidikan integrasi dengan menerima peserta didik berkebutuhan khusus pada 5 program keahlian Tata Boga, Tata Busana, Akomodasi Perhotelan, Tata Kecantikan dan Disain Komunikasi Visual. Program keahlian Tata Boga pada kelas XI ada 3 peserta didik berkebutuhan khusus menyandang ketunaan 2 orang tuna grahita dan 1 orang tuna rungu dan wicara, Peserta didik berkebutuhan khusus di kelas XII ada 2 orang menyandang ketunaan tuna grahita dan tuna rungu Walaupun hanya sedikit Peserta didik berkebutuhan khusus di kelas reguler bukan berarti tidak mendapatkan layanan pendidikan yang baik. 'Dalam melaksanakan pendidikan khusus diperlukan layanan pendukung yang paling mendasar bagi sekolah penyelenggara pendidikan khusus adalah kreatifitas guru dalam mengelola kelas seperti dalam hal pemilihan dan penggunaan metode dan media pembelajaran' (Florentina Anik, dkk, 2013:29). Adanya peserta didik berkebutuhan khusus di kelas reguler, guru mengalami kesulitan berkomunikasi dalam proses 
pembelajaran dan kesulitan untuk menentukan metode pembelajaran untuk peserta didik berkebutuhan khusus. Guru memerlukan persiapan ekstra dalam proses pembelajaran di kelas integrasi. Guru harus bisa memahami karakteristik peserta didik berkebutuhan khusus dan menentukan metode dan media pembelajaran yang tepat untuk peserta didik berkebutuhan khusus.

Dalam proses pembelajaran Tata Hidang kompetensi dasar membuat lipatan serbet atau napkin folding diharapkan anak terampil dalam membuat berbagai macam bentuk napkin folding. Untuk peserta didik berkebutuhan khusus merasa kesulitan dalam melakukan praktik napkin folding. Berdasarkan permasalahan yang telah diuraikan diatas, perlu adanya upaya dalam menentukan metode pembelajaran untuk meningkatkan hasil belajar peserta didik berkebutuhan khusus dalam praktik napkin folding, agar lebih meningkat.

Penulisan ini bertujuan untuk mendeskripsikan penerapan model STUF EX (Student Facilitator And Explaining) berbantukan hand out dalam meningkatkan hasil belajar praktik napkin folding pada peserta didik berkebutuhan khusus dan mendeskripsikan peningkatan hasil belajar peserta didik berkebutuhan khusus pada praktik napkin folding setelah menerapkan model STUF EX (Student Facilitator And Explaining) berbantukan hand out.

\section{Model Pembelajaran STUF EX}

Strategi yang dipilih dalam proses pembelajaran praktik napkin folding adalah dengan menerapkan model STUF EX (Student Facilitator And Explaining) berbantukan hand out. ' Model Student Facilitator and Explaining mempunyai arti metode yang menjadikan anak dapat membuat peta konsep maupun bagan untuk meningkatkan kreativitas anak dan prestasi belajar anak.( Agus Suprijono, 209) . Sehingga model pembelajaran Student Facilitator and Explaining menjadikan anak sebagai fasilitator dan diajak berpikir secara kreatif sehingga menghasilkan pertukaran informasi yang lebih mendalam dan lebih menarik serta menimbulkan percaya diri pada peserta didik untuk menghasilkan karya yang diperlihatkan kepada teman-temannya. Diharapkan peserta didik sebagai fasilitator dapat menjadi narasumber dan membantu peserta didik berkebutuhan khusus dalam 
proses pembelajaran. Model ini efektif meningkatkan komunikasi antara guru dan anak peserta didik serta komunikasi peserta didik dengan peserta didik. Sehingga pencapaian tujuan pembelajaran dapat terpenuhi secara optimal.

Langkah-langkah model pembelajaran Student Facilitator And Explaining adalah (1) Guru mendemonstrasikan atau menyajikan garis-garis besar materi pembelajaran. (2) Guru memberikan kesempatan kepada peserta didik untuk menjelaskan kepada peserta didik lainnya, misalnya melalui bagan atau peta konsep hal ini bisa dilakukan secara bergiliran atau acak. (3) Guru dan peserta didik menyimpulkan ide atau pendapat peserta didik. (5) Guru menerangkan semua materi yang disajikan saat itu.

Kompetensi dasar yang dipelajari dalam mata pelajaran Tata Hidang salah satunya Membuat Lipatan Serbet (Napkin Folding). Napkin folding adalah bentuk lipatan dari serbet yang biasanya diletakan diatas meja sebagai hiasan dan mempunyai bentuk penampilan yang indah dan menarik (. Dalam pembelajaran praktik napkin folding, penilaian dilakukan dengan menilai ketrampilan peserta didik dalam mempraktikkan macam-macm bentuk napkin folding. 'Keterampilan adalah kegiatan yang berhubungan dengan urat-urat syaraf dan otot-otot (neuromuscular) yang lazimnya tampak dalam kegiatan jasmaniah seperti menulis, mengetik, olah raga dan sebagainya, meskipun sifatnya motorik, namun keterampilan itu memerlukan koordinasi gerak yang teliti dan kesadaran yang tinggi'. (Muhibbin Syah, 1997: 119).

\section{Langkah-langkah Pelaksanaan}

Langkah-langkah pemecahan masalah menggunakan model Student Facilitator And Explaining yang dilakukan dalam kegiatan peoses pembelajaran di sekolah yang dilaksanakan dapat digambarkan secara garis besar meliputi perencanaan, pelaksanaan dan evaluasi.

Tahap Perencanaan, meliputi menyiapkan materi yang akan disampaikan pada anak, membuat Rencana Pelaksanaan Pembelajaran (RPP) yang berkaitan dengan materi yang akan diajarkan kepada anak, (menyiapkan hand out pembelajaran praktik napkin folding. 
Pada tahap pelaksanaan, disesuaikan dengan RPP yang telah dibuat sebelumnya yang terdiri dari 3 kegiatan yaitu kegiatan pendahuluan, kegiatan inti dan kegiatan penutup. Kegiatan Pendahuluan meliputi (1) Guru mengucapkan salam dan meminta satu peserta dididk memimpin berdoa sesuai dengan agama yang dianut masing-masing peserta didik, mengecek kehadiran peserta didik, (2) Guru melakukan apersepsi dengan mengajukan (pertanyaan mendasar) tentang pengetahuan sekitar napkin folding, (3) Guru menjelaskan tujuan pembelajaran yang akan dicapai dan garis-garis besar materi yang akan diajarkan, (4) Guru menanyakan tentang tugas pertemuan yang lalu tentang mencari materi melalui sumber media buku dan media internet. Kegiatan Inti yang dilakukan melaui langkah (1) Peserta didik diminta membetuk kelompok dengan anggota 4 sampai 5 orang. Peserta didik berkebutuhan khusus dalam kelompok dengan peserta didik lainnya sebagai teman sebaya, untuk membantu dan membimbing belajar peserta didik berkebutuhan khusus, (2) Peserta didik menyiapkan hand out dan peralatan untuk praktik napkin folding, (3) Guru memberikan kesempataan kepada peserta didik untuk mempraktikkan membuat napkin folding dengan dibantu hand out pembelajaran praktik napkin folding untuk peserta didik berkebutuhan khusus mempraktikkan jenis lipatan yang berbeda dan lebih sederhana disesuaikan dengan kemampuan peserta didik berkebutuhan khusus, (3) Peserta didik sebagai fasilitator mempraktikkan langkah-langkah membuat napkin folding sesuai dengan yang ada di hand out dalam kelompokny secara bergantian dan peserta didik lainnya mengikuti langkah-langkah yang dipraktikkan peserta didik fasilitator, (4) Guru mengamati dan menilai proses praktik napkin folding, (5) Setelah selesai praktik napkin folding, guru dan peserta didik menyimpulkan hasil praktik napkin folding, (6) Guru menerangkan semua materi praktik napkin folding. Kegiatan pentup meliputi kegiatan (1) Guru melakukan evaluasi dengan tanya jawab, (2) Peserta didik dan guru menyimpulkan materi yang telah dipelajari, (3) Guru memberikan tugas dalam bentuk laporan tentang materi praktik yang telah dipelajari, (4) Guru menginformasikan materi yang akan dipelajari pada pertemuan selanjutnya untuk mencari literatur atau referensinya, (5) Guru menutup kegiatan pembelajaran dengan berdoa dan salam. 
Tahap evaluasi kegiatannya dilakukan setelah siklus pertemuan yang tercantum dalam RPP selesai dilakukan. Evaluasi dilakukan dalam bentuk lembar kerja praktik untuk mengetahui tingkat pemahaman peserta didik berkebutuhan khusus dalam mempraktikkan macam-macam bentuk napkin folding dengan waktu 10 menit. Sehingga guru dapat mengamati adanya peningkatan hasil belajar peserta didik berkebutuhan khusus dalam parktik napkin folding.

\section{Hasil yang Dicapai ( Lesson Learn : pelajaran yang dapat diperoleh)}

Setelah menerapkan model pembelajaran STUF EX ( Student Facilitator And Explaining) dengan penekanan pada keaktifan anak, banyak perubahan yang terjadi pada peserta didik berkebutuhan khusus. Perubahan itu penulis ketahui dari observasi pada aktifitas peserta didik berkebutuhan khusus pada saat mengikuti pembelajaran dan hasil perkembangan belajar peserta didik berkebutuhan khusus. Perubahan itu antara lain bagi Peserta didik berkebutuhan khusus dapat menerima penjelasan dari temannya sebagai fasilitator. Sehingga peserta didik berkebutuhan khusus dengan senang hati mau mempraktikkan napkin folding sesuai langkahlangkah yang diajarkan.

Pengamatan terhadap peserta didik berkebutuhan khusus pada :

\section{Faradilla Oktaviani Parawangsa}

Peserta didik berkebutuhan khusus bernama Faradilla merupakan anak tergolong tuna grahita atau lambat belajar. Tuna grahita merupakan istilah yang digunakan untuk menyebut anak yang mempunyai kemampuan intelektual di bawah rata-rata. Retardasi mental atau dikenal dengan istilah disabilitas inteligensia (di Indonesia dikenal dengan nama tunagrahita) adalah individu yang mengalami keterbatasan mental (Jamaris, 2010 : 269). Hasil pemeriksaan psikologi Farah tergolong anak memiliki taraf kecerdasan mental Defectice/Sangat lambat. Farah mengalami hambatan dalam berpikir sehingga membutuhkan waktu yang lebih lama untuk menyelesaikan tugas belajarnya. Dalam proses pembelajaran dilakukan pendekatan dengan temannya sebagai fasilitator dengan memberikan instruksi berulang-ulang sampai memahami apa yang harus dilakukan. Praktik napkin folding instruksi 
satu macam napkin folding dipraktikkan berulang-ulang oleh temannya lalu ditirukan dengan bantuan. Hasil evaluasi praktik napkin folding dalam waktu 10 menit menyelesaikan 3 bentuk napkin folding dan walaupun bentuknya belum sesuai standar penilaian dilihat dari bentuk lipatan masih kurang rapi, Kreatifitas pemilihan jenis napkin folding masih bentuk yang paling sederhana dan tingkat kesulitan yang rendah. Sebelumnya hanya bisa menyelesaikan 1 bentuk napkin folding dalam waktu sepuluh menit dan bentuknya belum sesuai dengan standar penilaian. Untuk peserta didik reguler bisa menyelesaikan 10 bentuk napkin folding dalam waktu 10 menit tetapi standar untuk peserta didik berkebutuhan khusus kurang dari 10 bentuk dalam waktu 10 menit.

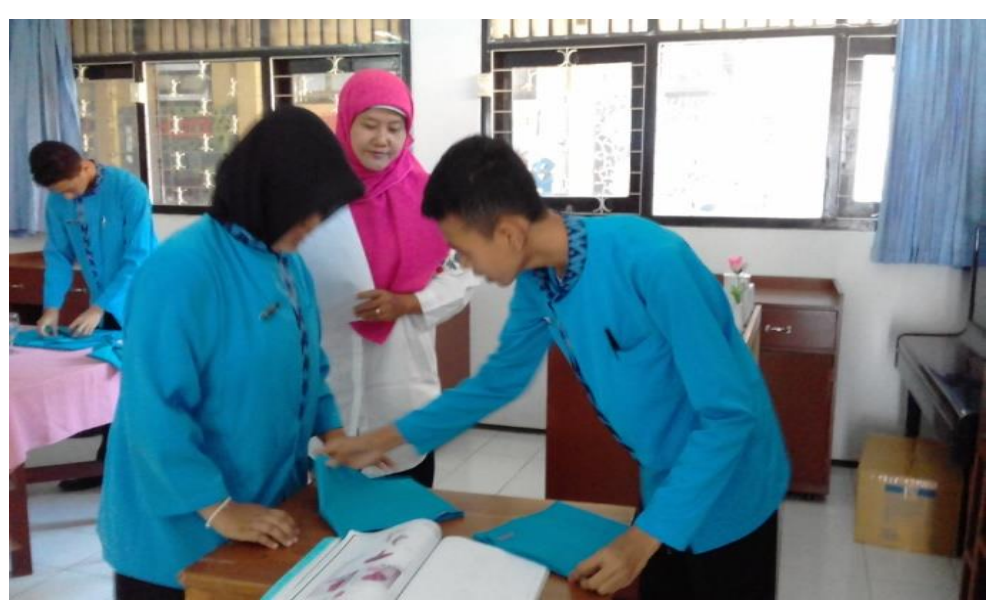

Gb.2.1. Farah praktik napkin folding dengan teman sebagai fasilitator

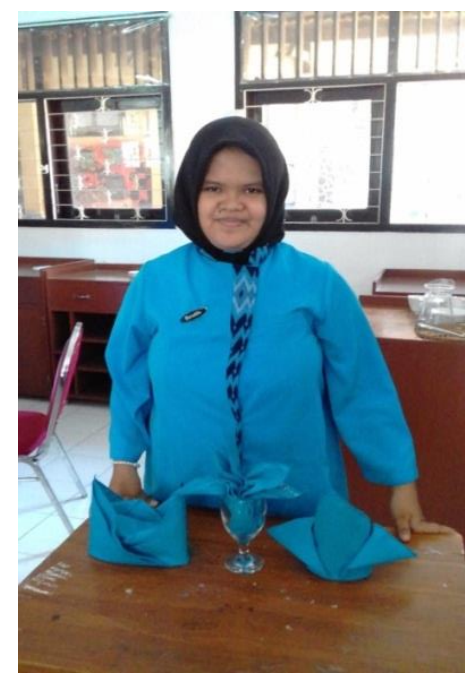

Gb2.2. Hasil praktik napkin folding farah 


\section{Fian Gusti Eka Palupi}

Peserta didik berkebutuhan khusus bernama Fian merupakan anak tergolong tunarungu dan tunawicara. Berdasarkan hasil pemeriksaan psikologi, Fian tergolong anak yang memiliki taraf kecerdasan Boderline/Lambat. Dalam proses pembelajaran Fian memerlukan latihan yang berulang secara terus menerus tetapi masih bisa mengikuti dengan baik. Karena tunarungu dan tunawicara memerlukan kominikasi berhadapan dengan Fian agar bisa melihat gerak bibir dan mimik. Proses pembelajaran praktik napkin folding memerlukan latihan yang berulang-ulang dan demontrasi secara langsung dan berhadapan. Setelah diterapkan model pembelajaran STUF EX. Hasil praktik Fian ada peningkatan karena melihat teman yang mempraktikkan langkahlangkah membuat nakin folding dan diikuti tahap demi tahap oleh Fian. Dari hasil evaluasi praktik napkin folding Fian mampu mempraktikkan 5 jenis napkin folding dalam waktu 10 menit dan memenuhi standar penilaian bentuknya jelas dan rapi, kreatifitas bentuk napkin folding masih bentuk sederhana.

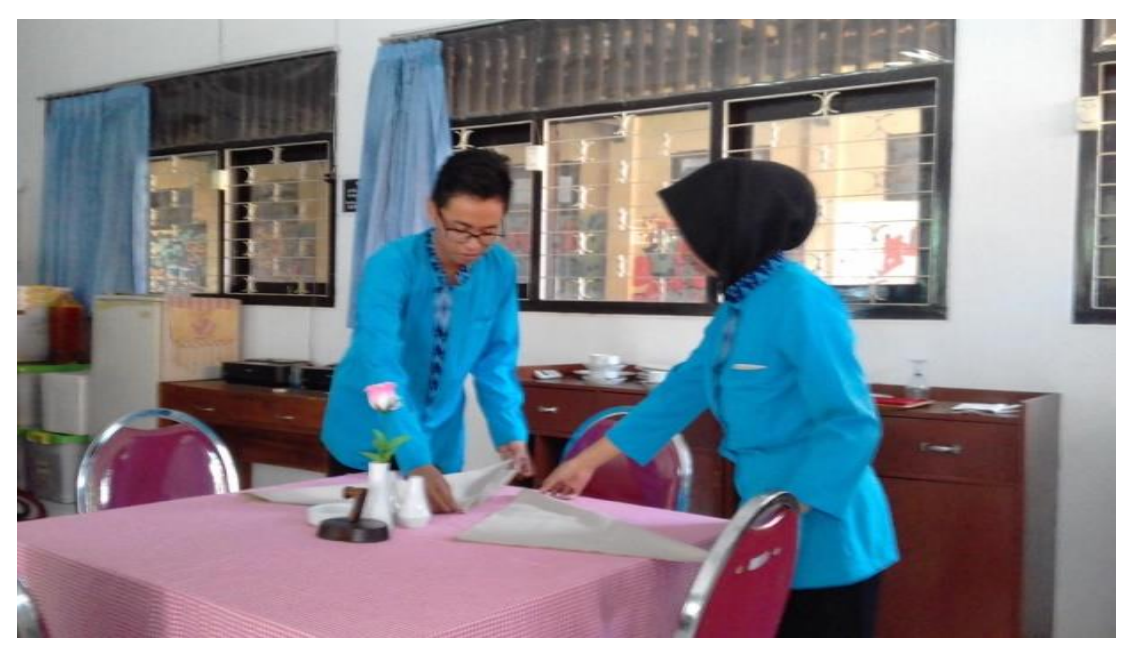

Gb2.3. Fian praktik napkin folding dibantu temannya sebagai fasilitator 


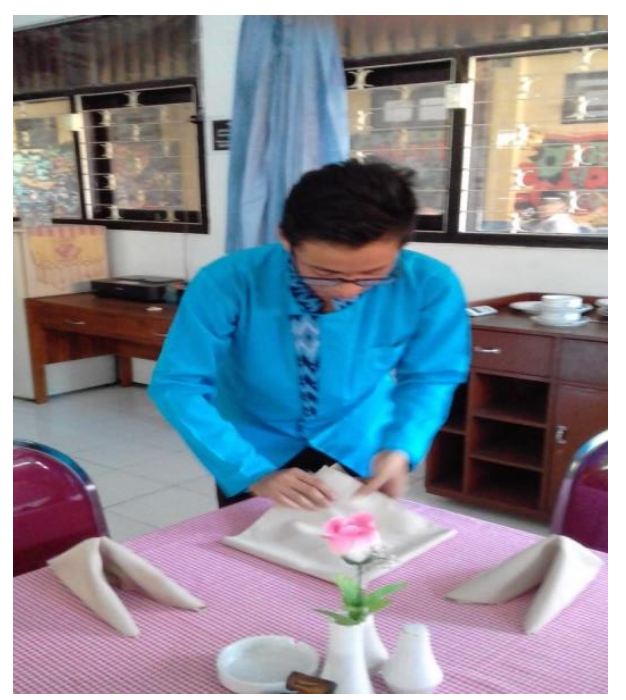

Gb.2.4. Fian mencoba praktik napkin folding tanpa dibantu temannya

\section{Pendukung dan Penghambat}

Dalam proses pelaksanaan pembelajaran dengan model Stuf Ex ( Student Facilitator And Explaining) terdapat faktor pendukung yang memungkinkan proses pembelajaran berjalan dengan baik dan optimal serta hasil yang didapat sesuai dengan tujuan proses pembelajaran, yaitu : (1) Peserta didik di kelas reguler sudah bisa menerima keberadaan peserta didik berkebutuhan khusus sehingga sangat membantu dalam proses pembelajaran, (2) Fasilitas yang ada di sekolah sangat membantu bagi peserta didik berkebutuhan khusus dalam proses pembelajaran, (3) Lingkungan yang kondusif di sekolah karena semua warga sekolah sudah bisa menerima perbedaan dan memiliki kepekaan sosial yang tinggi untuk menjalin komunikasi dengan peserta didik berkebutuhan khusus.

Terdapat beberapa kendala dalam melaksanaan pembelajaran dengan model Stuf Ex ( Student Facilitator And Explaining) yaitu : (1) Guru masih kesulitan untuk berkomunikasi dengan peserta didik berkebutuhan khusus. Sehingga proses pembelajaran terhambat karena peserta didik berkebutuhan khusus kurang bisa menerima penjelasan dari guru, (2) Pada saat peserta didik berkebutuhan khusus mengalami kebosanan dalam mengikuti pembelajaran diperlukan waktu dan penanganan khusus untuk peserta didik berkebutuhan khusus yang dibantu dengan guru luar biasa sebagai guru pendamping khusus. 


\section{Pengembangan (tindak lanjut)}

Alternatif pengembangan Untuk mengembangkan metode pembelajaran Student facilitator And Explaining, agar berdampak meningkatnya kualitas hasil pembelajaran dan berkembangnya kompetensi peserta didik berkebutuhan khusus agar semakin meningkat. Alternatif-alternatif pengembangan antara lain sebagai berikut : (1) Untuk mengantisipasi kesulitan guru dalam berkomunikasi dengan peserta didik berkebutuhan khusus. Semakin banyak guru yang diikutkan dalam pelatihan Guru Pendamping Khusus (GPK). Agar guru memiliki bekal tentang pengetahuan karakteristik peserta didik berkebutuhan khusus dan cara penangannya. (2) Peserta didik reguler diberikan sosialisasi tentang keberadaan peserta didik berkebutuhan khusus di sekolah reguler. Agar semua peserta didik reguler dapat menerima keberadaan peserta didik berkebutuhan khusus dan bersosialisasi, berkomunikasi dengan anak berkebutuha khusus dengan baik. (3) Fasilitas pembelajaran untuk peserta didik berkebutuhan khusus semakin dilengkapi oleh pihak sekolah, untuk memperlancar kegiatan pembelajaran bagi peserta didik berkebutuhan khusus.

\section{Simpulan}

Simpulan dari kegiatn ini adalah (1) Penerapan STUF EX (Student Facilitator And Explaining) berbantukan hand out dalam meningkatkan hasil belajar praktik napkin folding pada peserta didik berkebutuhan khusus telah dilaksanakan dengan baik sesuai dengan langkah-langkah yang ada. Hasil yang didapatkan peserta didik berkebutuhan khusus menjadi tertarik untuk belajar bersama teman-temannya, (2) Peranan guru dan teman di kelas intregasi sangat membantu proses belajar peserta didik berkebutuhan khusus sehingga mereka tidak merasa terabaikan. Pergaulan sosial dengan teman-teman yang mau menerima keadaan mereka menambah semangat peserta didik berkebutuhan khusus untuk belajar, (3) Model STUF EX (Student Facilitator And Explaining) berbantukan hand out dapat meningkatkan hasil belajar peserta didik berkebutuhan khusus atas nama Farah dan Fian. Peningkatan hasil belajar peserta didik berkebutuhan khusus dibuktikan dengan hasil praktik sebelum menggunakan model STUF EX, mereka kesulitan dalam praktik melipat serbet 
(napkin folding). Setelah menggunakan model STUF EX ada peningkatan hasil praktik melipat serbet (napkin folding) cukup sesuai dengan standar penilaian melipat serbet (napkin folding).

Dengan melihat dan merasakan banyaknya manfaat best practice ini, maka penulis memberikan saran agar di masa yang akan datang, inovasi ini dapat lebih dikembangkan sehingga kualitas dan hasil pembelajaran semakin meningkat. Berikut ini saran yang ditawarkan penulis, adalah Guru dalam mengajar di kelas intregasi dengan adanya peserta didik berkebutuhan khusus, perlu meningkatkan kompetensi dalam mendampingi dan mengajar peserta didik berkebutuhan khusus, untuk lebih memahami karakter peserta didik berkebutuhan khusus sehingga dalam proses pembelajaran peserta didik berkebutuhan khusus terakomodir untuk belajar, Guru juga perlu meningkatkan kreatifitasnya dalam menggunakan model dan media pembelajaran yang tepat di kelass intregasi. Model dan media pembelajaran yang tepat untuk peserta didik berkebutuhan khusus dalam proses pebelajaran sehingga ada peningkatan hasil belajar, Fasilitas dan alat yang diperlukan untuk pembelajaran peserta didik berkebutuhan khusus semakin dilengkapi oleh pihak sekolah sehingga peserta didik berkebutuhan khusus merasa nyaman untuk belajar.

\section{DAFTAR PUSTAKA}

Agus Suprijono (2009). Cooperative Learning Dan Aplikasi Paikem. Yogyakarta: Pustaka Belajar.

Florentina Atik,dkk (2013). Modul Pelatihan Pendidikan Inklusif Berbasis Sekolah.Jakarta:Kementerian Pendidikan dan Kebudayaan.

Jamaris, M. (2010). Orientasi baru dalam psikologi pendidikan. Jakarta: Yayasan Panamas Murni.

Syah, Muhibbin(2009) Psikologi Pendidikan dengan Pendekatan Baru. Bandung: Remaja Rasda Karya. 